\title{
Enhancement of Hybrid SPEEK Based Polymer-Cyclodextrin- Silica Inorganic Membrane for Direct Methanol Fuel Cell Application
}

\author{
Tutuk Djoko Kusworo*, Muhammad Fahmi Hakim and H. Hadiyanto \\ Departement of Chemical Engineering, University of Diponegoro Jl. Prof. Sudharto, Tembalang, Semarang, 50239, Indonesia \\ Phone/Fax: +62-24-7460058
}

\begin{abstract}
Direct methanol fuel cell (DMFC) is one of several types of fuel cells that use proton exchange membrane (PEM) as a liaison between the reaction at the cathode and anode. Polyether-ether ketone (PEEK) is one of the aromatic polymer that can be applied in DMFC because of its characteristics that are resistant to DMFC environment. The polymer is also quite easy in the sulfonation process using concentrated sulfuric acid. However the role of polyether-ether ketone as DMFC membrane material is still lack of advantage due to its low conductivity and therefore the modification is required to increase the value of proton conductivity of the membrane. The purpose of this experiment is to modify the membrane (sPEEK) with the addition of cyclodextrins-silica, additive variation charge of $2 \%, 6 \%$ and $10 \%$, time and temperature were fixed at 4 hours and $65{ }^{\circ} \mathrm{C}$. The results showed the best results of membrane sPEEK was obtained at the addition of polymer-cyclodextrin-silica $10 \%$ with the membrane characteristics of ion exchange capacity of $2.19 \mathrm{meq} / \mathrm{g}$ polymer, the degree of sulfonation of $81 \%$, methanol permeability of $3.09 \times 10^{-9} \mathrm{~cm}^{2} / \mathrm{s}$ and water uptake membrane of $64 \%$.
\end{abstract}

Keywords: Direct Methanol Fuel Cell, Poly(ether ether ketone), cyclodextrin-silica, sulfonation, ionic conductivity.

Article History: Received January 18 ${ }^{\text {th }}$ 2017; Received in revised form April 21 ${ }^{\text {st }}$ 2017; Accepted June 22 nd 2017; Available online How to Cite This Article: Kusworo, T.D., Hakim, M.F. and Hadiyanto, H. (2017) Enhancement of Hybrid SPEEK Based PolymerCyclodextrin-Silica Inorganic Membrane for Direct Methanol Fuel Cell Application. International Journal of Renewable Energy Development, 6(2), 165-170.

https://doi.org/10.14710/ijred.6.2.165-170

\section{Introduction}

Direct methanol fuel cells (DMFC), one type of fuel cell that attracts attention at this moment as an alternative energy source that is environmentally friendly, has high efficiency and can be operated at a relatively low temperature (Shang et al., 2009). DMFC is the most important component in the membrane, besides as a barrier between the two electrodes, it also serves as a mean of transport of protons from the anode to the cathode. The current electrolyte membrane used for DMFC is Nafion®. However, Nafion ${ }^{\circledR}$ has several limitations such as high cost of production and methanol cross-over that cause the fuel-losses and lowering the overall voltage performance (Xue et al., 2006). Nafion ${ }^{\circledR}$ is a membrane made of fluoro polymer by adding branched-chain group containing sulfonate (Zhong et al., 2009).
Nafion ${ }^{\circledR}$ ability for proton conductor is quite good with conductivity of $0.1 \mathrm{~S} / \mathrm{cm}$ (product DuPontTM Information) and methanol permeability of $2.86 \times 10^{-6}$ $\mathrm{cm}^{2} / \mathrm{s}$. The occurrence of methanol crossover and high prices become obstacles to commercialize DMFC (Mahreni et al., 2009). The current researchs are focused on developing alternative membranes for fuel cells as a subtitution for Nafion ${ }^{\circledR}$ (Hartanto et al., 2007). Several studies reported electrolyte membrane alternatives that have been developed in various polymers are polysulfone (Genove et al, 2001), polystyrene (Carrette, 2001), polyether-ether ketone (PEEK) (Xing, 2004). The polymers in order to function as an electrolyte, the electrolyte needs to be added include a sulfonate group, the process of adding the electrolyte group called the sulfonation process (Silva et al., 2008). Polyether ether ketone (PEEK) is an aromatic polymer which is very appropriate in DMFC applications because it has properties of

\footnotetext{
* Corresponding author: tdkusworo@che.undip.ac.id
} 
Citation: Kusworo, T.D., Hakim, M.F. and Hadiyanto, H. (2017) Enhancement of Hybrid SPEEK Based Polymer-Cyclodextrin-Silica Inorganic Membrane for Direct Methanol Fuel Cell Application. Int. Journal of Renewable Energy Development, 6(2), 165-170, https//doi.org/10.14710/ijred.6.2.165-170

P a g e | 166

chemical resistance, mechanical stability and good thermal stability (Maab and Nunes, 2010). PEEK is also quite easy and simple in the sulfonation process using concentrated sulfuric acid (Silva et al., 2008).

Demands for electrolyte membrane that can be applied to DMFC is as stable chemical, electrochemical, mechanical, acidic, proton conductor, well, can adsorb water and methanol permeability as small as possible (Roelofs et al., 2010). Transport of protons in the electrolyte membrane is determined by negatively charged groups (usually sulfonate, $\mathrm{SO}_{3} \mathrm{H}$ ), the greater conductivity sulfonate group-would be even greater. In addition, sulfonate cluster in the membrane also requires water to facilitate the transport of protons, thus increasing the proton conductivity (Handayani et al., 2007). The results of the studies of PEEK as DMFC membrane material showed the characteristics of the electrolyte membrane could be improved by additive modification technique. This is because the value of the conductivity of PEEK membrane is still relatively low. The addition of filler materials have been previously reported such as silica and $\mathrm{H}$-zeolite, tungstosilicic acid, silica-aluminum oxide, polyvinyl alcohol and calcium oxide, chitosan-silica, salt Cs - fosfotungstic acid (Cs-PWA) (Handy et al., 2007; Ismail et al., 2009; Mat et al., 2009; Zulfikar et al., 2009; Hidayati et al., 2015). However, the produced membranes from previous studies still have a low conductivity and high methanol permeability. In fact, higher electrolyte membrane for DMFC application is an advantage but the ionic conductivity of methanol permeability must be as small as possible. Therefore, further research is necessary to develop the manufacture of membranes that have mechanical and chemical stability, which is supported by the filler material to stabilize the absorption of water or methanol and increase the value of proton conductivity.

There are several methods have been used to improve the operation of sPEEK such as creating a composite membrane with an inorganic material, mixing with polymer membranes and other surface modification such as plasma treatment and a gradual reaction, surface coating or a combination of these methods. The addition of modifier that can be added to the casting solution is the best choice to modify the surface of the membrane in one step. Several types of filler that can be added as a modifier to sPEEK include inorganics oxide for example $\mathrm{SiO} 2$, for example, silica clay-SO3H and conductive polymers for example cyclodextrin.

Cyclodextrin is a conductive polymer with a toroidshaped structures (truncated cone), the outer surface is hydrophilic and hydrophobic inner surface (Hiremath et al., 2008). Cyclodextrin structure is expected to improve the absorption of water as a proton membrane transport, which means increasing the value of the membrane conductivity without reducing the mechanical stability of the membrane.
Cyclodextrin and its derivatives can form inclusion complexes of compounds that can increase the solubility of the compound, binding of volatile compounds, protect labile compounds, reducing the toxicity of a compound effect and improve the texture (Shende et al., 2015). Characteristics of cyclodextrin is expected to improve morphology and texture of the membrane SPEEK that is expected to increase the density of the membrane structure, and reducing permeation of methanol through the membrane. Cyclodextrin is a material that has potential for use as a filler in the membrane sPEEK.

Silica gel is a form of silica produced by sol agglomeration of sodium silicate (NaSiO2). This sol may be dehydrated such it turns into glassy solids or granules that are not elastic. These properties make the silica gel can be used as an absorbent, dryers and sustainer of the catalyst. Silica gel prevents the formation of excessive moisture before it happens, these properties are expected to increase the absorptive capacity of the membrane without reducing the mechanical properties of the membrane when silica packing material added to SPEEK, this is due to excessive absorption of water will reduce the mechanical stability of the membrane.

Therefore, the effect of combination of silica and cyclodextrin as inorganic filler in the sulfonated polyetherether ketone (sPEEK) membranes were investigated in this article. The electrolyte hybrid sPEEK membrane was applied to the Direct Methanol Fuel Cell (DMFC). The effect of the addition of cyclodextrin-silica filler material on the degree of sulfonation (DS), ion exchange capacity (IEC), methanol permeability and water uptake is also studied.

\section{Materials and Methods}

\subsection{Materials selection}

Polyether-ether ketone and B-Cyclodextrin was supplied by Sigma Aldrich. The polymers were dried in a vacuum oven at $100 \mathrm{oC}$ during 12 hours before dope preparation; N,N-Dimethylacetamide from Merck was used as the solvent due to its low toxicity. Sulfuric acid was supplied by Merck.

\subsection{Methods}

Five grams of PEEK was dissolved in $100 \mathrm{~mL}$ of concentrated sulfuric acid, the sulfonation process carried out at a temperature of $65^{\circ} \mathrm{C}$ sulfonation at a fixed time is 4 hours. To end the reaction, the polymer solution was precipitated in cold water overnight, it will form a solid polymer. The polymer is separated from the mixture and washed with distilled water repeatedly until the $\mathrm{pH}$ is neutral. The sPEEK was dried in an oven at room temperature for 12 hours and then at $60^{\circ} \mathrm{C}$ for 12 hours. 
The membranes was prepared by phase inversion method, namely sPEEK dry solids dissolved in a solution of dimethylacetamide (DMAC) with stirring for 4 hours. A certain amount of cyclodextrin and silica, in accordance with pre-determined percentage, mixed into a solution sPEEK. Membrane printing was carried out by pouring the solution over the petri dish in order to obtain a membrane with a thickness of about $80 \mu \mathrm{m}$. Drying of membrane layer was conducted in an oven at $50^{\circ} \mathrm{C}$ for 48 hours.

Water uptake membranes were measured at room temperature by calculating the difference of wet and dry weight of the membrane. Wet weight was determined after soaking the membrane in water for 48 hours. The membrane surface was wiped with tissue paper and weighed or measured immediately. The dry weight/length of the membrane was obtained by drying in an oven at a temperature of $120^{\circ} \mathrm{C}$ for 2 hours.

$$
W T U=\frac{W_{w e t}-W_{d r y}}{W_{d r y}} \times 100 \% \ldots \ldots \ldots . .(1)
$$

where WTU, Wwet and Wdry represents water up take, in weight percent (wt.\%), and weight of the wet and dried membrane, respectively.

Methanol permeability was measured at room temperature using diffusion cells. The membrane was placed between two cells (A and B). At first cell A methanol solution containing $3 \mathrm{M}(\mathrm{CA})$ as the feed side, and B cells contains distilled water as the permeate side. Each cell was stirred for 2.5 hours, then the solution in the B cells was analyzed concentrations of methanol (CB). Methanol concentration was measured based on the density of the solution. The equation for calculating permeabilatas methanol:

$$
C B=\frac{A}{V B} \frac{D K}{L} C A\left(t-t_{0}\right)
$$

where $\mathrm{CA}$ and $\mathrm{CB}$ is the concentration of methanol in the glasses $\mathrm{A}$ and $\mathrm{B} ; \mathrm{A}$ and $\mathrm{L}$ are the cross-sectional area of the membrane and the membrane thickness; D and $\mathrm{K}$ are methanol diffusivity and the partition coefficient between the membrane with a solution. D is assumed to be constant throughout the membrane surface and $\mathrm{K}$ is not influenced by concentration. Products from DK, $\mathrm{cm}^{2} / \mathrm{s}$.

The degree of sulfonation (DS) was calculated from ion exchange capacity (IEC) by using equation (4) and equation (5). IEC is the ratio of the number of hydrogen ions that can be redeemed per dry weight of the sample. IEC measurements were carried out bu using titration methods. Samples membrane soaked in a solution of $1 \mathrm{M} \mathrm{NaCl}$ for 3 days, then titrated with $0.01 \mathrm{M} \mathrm{NaOH}$ and phenolphthalein indicator until the pink end point. $\mathrm{SO} 3 \mathrm{H}$ molar amount present in the sample sPEEK-H can be defined by the equation:

$$
\begin{aligned}
& \text { meqSPEEK }-H(N . V)_{\mathrm{NaOH}}-(N . V) \ldots \ldots \ldots . .(3) \\
& I E C=\frac{\text { meqSPEEK }-H}{\text { weight_of_sample }} \ldots \ldots \ldots \ldots \ldots \ldots \ldots . .(4) \\
& D S=\frac{288 .(\text { IEC })}{1000-103 .(\text { IEC) }} \times 100 \% \ldots \ldots \ldots \ldots \ldots . .(5)
\end{aligned}
$$

\section{Results and Discussion}

\subsection{The effect of the concentration cyclodextrin-silica blending to sPEEK properties.}

\subsubsection{Water Uptake of sPEEK Membrane}

The addition of cyclodextrin-silica fillers with a composition of $2 \%, 6 \%, 10 \%$ increase water uptake value of the membrane 2 times than value of water uptake Nafion ${ }^{\circledR}$ membrane or sPEEK without stuffing material. These results showed a good improvement to the membrane in DMFC applications because the higher the membrane's ability to absorb water, the membrane conductivity value also increases. Figure 1 shows that the composite membrane sPEEKcyclodextrin-silica has a water uptake value greater than the pure sPEEK membrane and the Nafion ${ }^{\circledR}$ membrane (Hiremath et al., 2008).

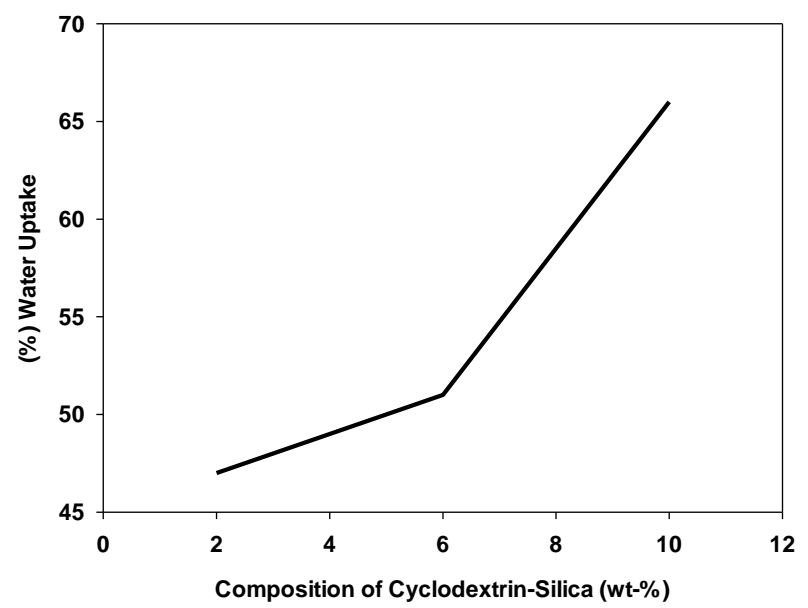

Fig. 1 The value of water uptake sPEEK-cyclodextrin-silica

The water uptake test shows that the presence of cyclodextrine in sPEEK membrane increases the membrane absorption up to $64 \%$. The surface of cyclodextrine is hydrophilic which highly absorbs the water. Moreover, the sulfonation process and silica addition also increase the water absorption. This could be due to the generation of sulfonate group and silanol (Si-OH) that greatly reacts with water. However, the absorbed water was controlled by the presence of the control cavity surface in a hydrophobic region (Hartanto et al., 2007). 
Citation: Kusworo, T.D., Hakim, M.F. and Hadiyanto, H. (2017) Enhancement of Hybrid SPEEK Based Polymer-Cyclodextrin-Silica Inorganic Membrane for Direct Methanol Fuel Cell Application. Int. Journal of Renewable Energy Development, 6(2), 165-170, https//doi.org/10.14710/ijred.6.2.165-170

P a g e | 168

Table 1

The effect of cyclodextrin-silica to water uptake

\begin{tabular}{|c|c|c|c|}
\hline No & Membrane & $\begin{array}{c}\text { Compo- } \\
\text { sition } \\
(\%)\end{array}$ & $\begin{array}{c}\text { Water } \\
\text { Uptake (\%) }\end{array}$ \\
\hline 1 & Nafion ${ }^{\circledR} *$ & & 37 \\
\hline 2 & SPEEK ** & & 20 \\
\hline 3 & $\begin{array}{l}\text { SPEEK-cyclodextrin- } \\
\text { silica }\end{array}$ & 2 & 36 \\
\hline 4 & $\begin{array}{l}\text { SPEEK-cyclodextrin- } \\
\text { silica }\end{array}$ & 6 & 50 \\
\hline 5 & $\begin{array}{l}\text { SPEEK-cyclodextrin- } \\
\text { silica }\end{array}$ & 10 & 64 \\
\hline
\end{tabular}

\subsubsection{Methanol Permeability}

The addition of cyclodextrins-silica composition of $2 \%, 6 \%, 10 \%$ as stuffing materials composite materials sPEEK membrane permeability caused a decline in methanol. This is due to the cyclodextrinsilica absorbed methanol through the cavity of cyclodextrin. It causes a small fraction of methanol diffuses through the membrane, this result is in accordance with the previous study conducted by Tao et al, (2011). Figure 2 shows that the composite membrane sPEEK-cyclodextrin-silica has a smaller methanol permeability of the membrane and the Nafion ${ }^{\circledR}$ membrane pure sPEEK.

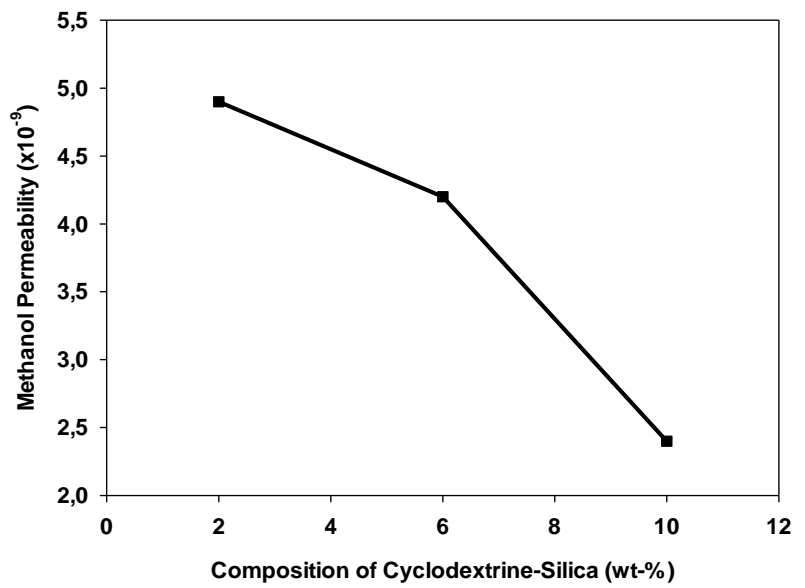

Fig. 2 Methanol permeability sPEEK-cyclodextrin-silica

The addition of fillers cyclodextrin-silica has been able to improve the permeability properties methanol sPEEK membranes, it is proved that the silica and cyclodextrin has absorbed methanol and water so only a small portion of methanol through the membrane, in addition to the cyclodextrin as host molecule form inclusion complexes that surrounds and binds guest molecule in this case methanol. Methanol is enveloped by the host molecules forming covalent bonds in the cyclodextrin cavity and form a tetrahedral strong therein, the power of attraction of methanol make it difficult to be separated from the host molecule, this is what causes the increased solubility, density and stability of the membrane (Hiremath et al., 2008).

\subsection{The effect of sulfonation method on sPEEK properties}

\subsubsection{Ion Exchange Capacity (IEC)}

IEC measurements and DS carried out to see how many sulfonate groups attached to the polymer during a sulfonation process. IEC is the ratio of the number of hydrogen ions that can be redeemed per dry weight of the sample, the measurement by titration methods. Table 2 showed IEC values and DS sPEEKcyclodextrin-silica, the higher degree of sulfonation and the capacity of the ion exchanger then the proton conductivity will be even greater. In this study, the sulfonation process has been performed at a constant temperature $\left(65^{\circ} \mathrm{C}\right)$. This condition is considering previous studies related to the effect of sulfonation temperature on the characteristics of the membrane. The higher temperature of sulfonation process, the degree of sulfonation greatly increased. It means that proton conductivity of membrane is also greater. However, the temperature process higher than $70^{\circ} \mathrm{C}$ reduces the mechanical stability of the membrane (Handayani et al., 2007).

From the analysis results obtained degrees sulfonation IEC row 77, 78, 81\% are in general the result is said to be in the range of high DS value which can produce large conductivity values. The IEC value and membrane DS are vary with the different methods of sulfonation process. The introduction of cyclodextrin-silica during sulfonation process expands the presence of sulfonate group in the membrane. The highest value of IEC and DS of the membrane were showed by the sPEEK membrane with 10 wt-\% cyclodextrin-silica loading. These results suggest that sPEEK-cyclodextrin-silica composition in range of 2 $10 \%$ can be applied to DMFC.

Table 2

\begin{tabular}{|c|c|c|c|c|}
\hline No & Membrane & wt- $\%$ & $\begin{array}{l}\text { IEC } \\
\mathrm{meq} / \mathrm{g}\end{array}$ & DS \% \\
\hline 1 & $\begin{array}{l}\text { SPEEK- cyclodextrin- } \\
\text { silica }\end{array}$ & 2 & 2,1 & 77 \\
\hline 2 & $\begin{array}{l}\text { SPEEK- cyclodextrin- } \\
\text { silica }\end{array}$ & 6 & 2,0 & 78 \\
\hline 3 & $\begin{array}{l}\text { SPEEK- cyclodextrin- } \\
\text { silica }\end{array}$ & 10 & 1,7 & 81 \\
\hline
\end{tabular}

\subsection{Characterization Scanning Electron Microscopy (SEM)}

To determine the morphology and electron dispersive spectroscopy (EDS) composite membrane is evaluated by scanning electron microscopy (SEM) with a magnification of 500x and 3000x (Figure 3). 

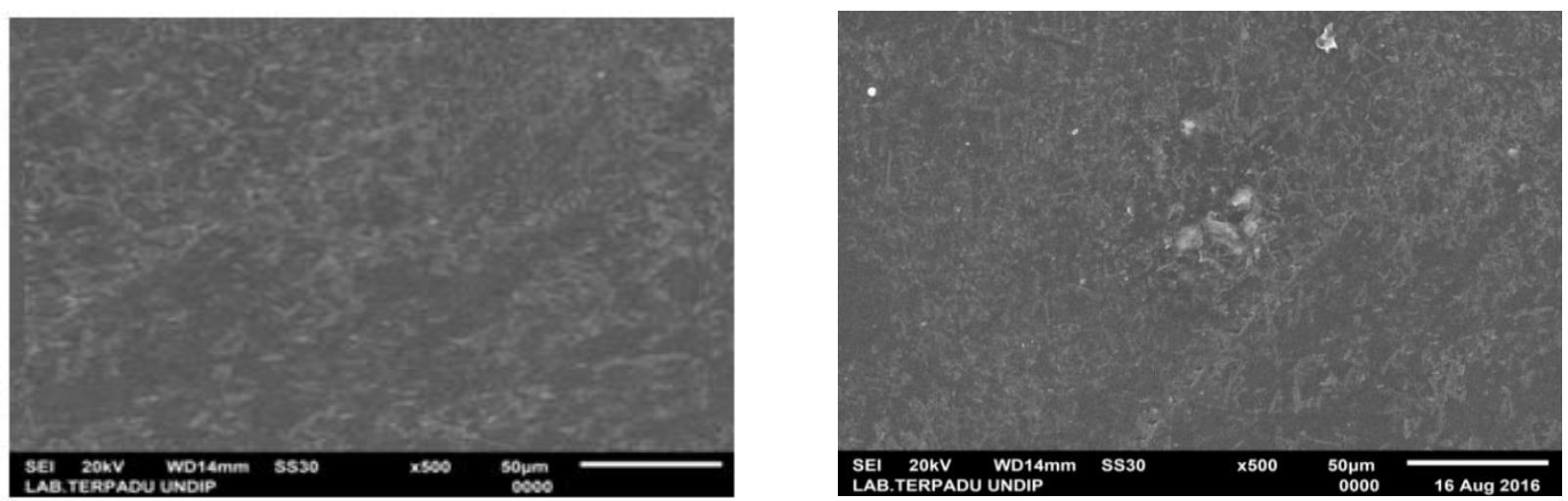

Fig. 3 Morphology composite silica membrane-cyclodextrin sPEEK $10 \%$ with magnification (a) $500 \mathrm{x}$ (b) $3000 \mathrm{x}$

Table 3

EDX composite membrane sPEEK-cyclodextrin-silica

\begin{tabular}{|c|c|c|c|c|c|c|c|c|}
\hline Element & $\mathbf{V}$ & $\begin{array}{c}\text { Mass } \\
(\%)\end{array}$ & Sigma & $\begin{array}{c}\text { Mol } \\
(\%)\end{array}$ & Compound & $\begin{array}{c}\text { Mass } \\
(\%)\end{array}$ & Cation & $\mathbf{K}$ \\
\hline C K & 0.277 & 68.98 & 0.28 & 84.35 & $\mathrm{C}$ & 68.98 & 0.00 & 71.82 \\
\hline $\mathrm{O}$ & & 7.84 & & & & & & \\
\hline F K & 0.677 & 16.52 & 0.21 & 12.77 & $\mathrm{~F}$ & 16.52 & 0.00 & 10.42 \\
\hline $\mathrm{Na} \mathrm{K}$ & 1.041 & 0.17 & 0.02 & 0.05 & $\mathrm{Na}_{2} \mathrm{O}$ & 0.23 & 0.36 & 0.31 \\
\hline Mg K & 1.253 & 0.32 & 0.03 & 0.02 & $\mathrm{MgO}$ & 0.54 & 0.65 & 0.55 \\
\hline $\mathrm{Si} \quad \mathrm{K}$ & 1.739 & 0.12 & 0.03 & 0.03 & $\mathrm{SiO}_{2}$ & 0.25 & 0.21 & 0.28 \\
\hline $\mathrm{S} \quad \mathrm{K}$ & 2.307 & 4.64 & 0.03 & 0.12 & $\mathrm{SO}_{3}$ & 11.59 & 7.09 & 12.88 \\
\hline $\mathrm{Ca} \mathrm{K}$ & 3.690 & 0.86 & 0.12 & 0.04 & $\mathrm{CaO}$ & 1.20 & 1.05 & 2.40 \\
\hline $\mathrm{Cu} \quad \mathrm{K}$ & 8.040 & 0.55 & 0.04 & 0.06 & $\mathrm{CuO}$ & 0.69 & 0.43 & 1.30 \\
\hline Total & & $100 \%$ & & $100 \%$ & & $100 \%$ & 9.78 & \\
\hline
\end{tabular}

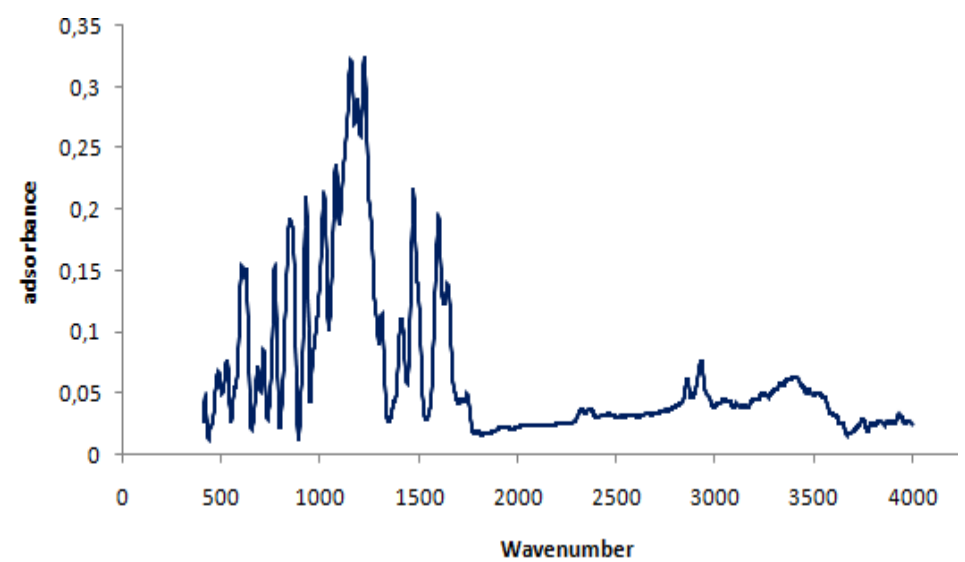

Fig. 4 Spectra of composite membranes Graph sPEEK-cyclodextrin-silica 10\%

Figure 3 shows a comparison of the composite sPEEK membrane and sPEEK-cyclodextrin-silica $10 \%$. The sPEEK membrane surface morphology has less dense and asymmetric, while the membrane surface morphology sPEEK-cyclodextrin-silica is denser and symmetrical although there was some buildup of the packing material in a section that is caused by the dissolution process stuffing materials less than the maximum. Table 3 shows the component elements-the building blocks of membranes, including an impurity contained in the composite membrane Speek-cyclodextrin-silica derived from silica sand that contains $\mathrm{Mg}, \mathrm{Ca}, \mathrm{Cu}$ and $\mathrm{F}$.

\subsection{Fourier Transform Infra Red (FTIR)}

To determine the blending cyclodextrin-silica going well, we conducted an analysis of FTIR sPEEK- 
Citation: Kusworo, T.D., Hakim, M.F. and Hadiyanto, H. (2017) Enhancement of Hybrid SPEEK Based Polymer-Cyclodextrin-Silica Inorganic Membrane for Direct Methanol Fuel Cell Application. Int. Journal of Renewable Energy Development, 6(2), 165-170, https//doi.org/10.14710/ijred.6.2.165-170

P a g e | 170

cyclodextrin-silica, with the results of the analysis as shown in Figure 4. Figure 4 shows observations functional groups on the silica in the silica-speekcyclodextrin $10 \%$. The result also concluded that the main peak associated with the functional groups on the silica is the wave number of $3444.6 \mathrm{~cm}^{-1}$ which is the - $\mathrm{OH}$ (hydroxyl group) that indicate the presence of hydroxyl groups of water molecules hydrated. Additionally peak wave number of $1095.5 \mathrm{~cm}^{-1}$ indicates the presence of functional groups Si-O-Si. The existence of functional groups $\mathrm{Si}-\mathrm{O}-\mathrm{Si}$ strengthened with the peak wave number of 470.6 $\mathrm{cm}^{1}$, which is the bond of Si-O (Adam, 2006).

\section{Conclusion}

This study has produced membrane sPEEKcyclodextrin-silica $2 \mathrm{wt} \%, 6 \mathrm{wt} \%$ and $10 \mathrm{wt} \%$ using processes of sulfonation. The effect of adding cargo stuffing materials cyclodextrin-silica $2 \mathrm{wt} \%, 6 \mathrm{wt} \%$ and $10 \mathrm{wt} \%$ of the membrane sPEEK is rising along with the addition of performance DMFC charge stuffing materials in terms of the value of water uptake, methanol permeability and the membrane morphology. The process of sulfonated PEEK membranes and stuffing materials cyclodextrin-silica can increase the value of ion exchange capacity and the degree of sulfonation and provide DMFC performance results are better than without the sulfonation process the packing material. The best result was shown by membrane sPEEK-cyclodextrinsilica $10 \mathrm{wt} \%$ with the highest degree of sulfonation reached $81 \%$ and the value of ion exchange capacity of $1.7 \mathrm{meq} / \mathrm{g}$, methanol permeability which is lower than that of Nafion ${ }^{\circledR} 3,0 \times 10^{-9}$ and water uptake value $64 \%$, so that the electrolyte membrane speek-cyclodextrinsilica $10 \%$ has the potential to be applied in a DMFC.

\section{Acknowledgments}

Authors would thank waste treatment Laboratory and Integrated Laboratory Unit, Diponegoro University for the facilities.

\section{References}

Adam, F.K,. Kandasamy, and S, Batakrishnan. (2006). Rice Husk Ash Silica a Support Material for Ruthenium Based Heterogenous Catalyst. Journal of Physical Science, 17(2), 13.

Carrette, L., Friedrich, K. A. and Stimming, U. (2001), Fuel Cells - Fundamentals and Applications. Fuel Cells, 1, 5-39.

Doğan, H., Inan, T.Y., Unveren, E., and Kaya, M., (2010). Effect of cesium salt of tungstophosphoric acid (Cs-TPA) on the properties of sulfonated polyether ether ketone (SPEEK) composite membranes for fuel cell applications.Int. Journal of Hydrogen Energy, 35, 7784-7795.

Genova-Dimitrova, B. Baradie, D. Foscallo, C. Poinsignon, J.Y. Sanchez. (2001) Ionomeric membranes for proton exchange membrane fuel cell (PEMFC): sulfonated polysulfone associated with phosphatoantimonic acid. Journal of Membrane Science, 185 (1), 59-71.
Handayani, S., Purwanto, W.W, Dewi, E.L. and Soemanto, R.W. (2007) Sintesis dan Karakterisasi Membran Elektrolit Polieter- Eter Keton Tersulfonasi. Jurnal Sains Materi Indonesia, 8(2), 1411 - 1098

Hartanto, S., Handayani, S., Marlina, L. and Latifah, (2007) Pengaruh Silika pada Membran Elektrolit berbasis PEEK. Jurnal Sains Materi Indonesia. 8(3), 205-208.

Hidayati, N., Mujiburohman, M., Purnama, H., Hakim, M.F. (2015) Karakteristik Membran Komposit PoliEter Eter KetonTersulfonasi untuk Direct Methanol Fuel Cell. Proceedings of Kejuangan Chemical Engineering National Seminar, Indonesia. 1693-4393.

Hiremath, S.N., Raghavendra, R. K., Sunil, F., Danki, L. S., Rampure, M. V., Swamy, P. V., Bhosale, U. V. (2008) Dissolution Enhancement of Gliclazide by Preparation of Inclusion Complexes with B -cyclodextrin, Asian Journal of Pharmaceutics. 2(1), 73-76.

Ismail, A.F., Othman, N.H., Mustafa, A. (2009) Sulfonated polyether ether ketone composite membrane using tungstosilicic acid supported on silica-aluminium oxide for direct methanol fuel cell (DMFC). Journal of Membrane Science, 329, 18-29.

Maab, H., and Nunes, S.P. (2010) Modified sPPEK membranes for direct methanol fuel cell. Journal of Power Sources, 195, 4036-4032.

Mahreni, A., Mohamad, A.B., Kadhum, A.A.H., Daud, W.R.W., Iyuke, S.E. (2009) Nafion ${ }^{\circledR} /$ silicon oxide / phospho-tungstic acid nanocomposite membrane with enhanced proton conductivity. Journal of Membrane Science, 327, 32-40.

Mat, N.C. and Liong, A. (2009) Chitosan - Poly(Vinyl Alcohol) and Calcium Oxide Composite Membrane for Direct Methanol Fuel Cell Applications. Engineering Letters, Advance Online Publication.

Roelofs, K.S., (2010) Sulfonated Poly(Ether Ether Ketone) Based Membranes For Direct Ethanol Fuel Cells. PhD Dissertation, Faculty of Energy and bioengineering, Universitat Stuttgart.

Shang, F., Li, L., Zhang, Y. and Li, H. (2009) PWA/Silica/PFSA Composite Membrane for Direct Methanol Fuel Cells. Journal of Material Science. 44, 4383-4388.

Shende, P. K. (2015) Effect of inclusion complexation of meloxicam with Beta-cyclodextrin and Beta-cyclodextrinbased nanosponges on solubility, in vitro release and stability studies. Colloids and Surfaces B: Biointerfaces. 136, $105-110$.

Silva,A.L., Takase, I., Pereira, R. P., and Rocco, A. M. (2008) Poly(styrene-co-acrylonitrile) based protonconductive membrans. European Polymer Journal. 17, 1462-1474.

XueSong, Yin, G., Cai, K., Shao, Y. (2007) Permeabilities of methanol, ethanol and dimethyl ether in new composite membranes: A comparison with Nafion ${ }^{\circledR}$ membranes. Journal of Membrane Science, 289, 51-57.

Zhong,S., Liu, C., Na, H. (2009) Preparation and properties of UV irradiation-induced crosslinked sulfonated poly(ether ether ketone) proton exchange membranes. Journal of Membrane Science, 326, 400-407.

Zulfikar, Ali, M.Wahyuningrum, D. and Berghuis, N.T. (2009) Pengaruh Konsentrasi Kitosan terhadap Sifat Membran Komposit Kitosan-Silika untuk Sel Bahan Bakar. Proceedings of Seminar Kimia Bersama UKM-ITB VIII Bandung, Indonesia. 